\title{
Nagra/PSI Chemical Thermodynamic Data Base 01/01
}

\author{
By W. Hummel ${ }^{1, *}$, U. Berner ${ }^{1}$, E. Curti ${ }^{1}$, F. J. Pearson ${ }^{2}$ and T. Thoenen ${ }^{1}$ \\ ${ }^{1}$ Paul Scherrer Institut, Waste Management Laboratory, CH-5232 Villigen PSI, Switzerland \\ 2 Ground-Water Geochemistry, 411 East Front St., New Bern, NC 28560-4916, USA
}

(Received August 22, 2001; accepted April 11, 2002)

\section{Database / Thermodynamic equilibrium constants / Radionuclides}

Summary. The Nagra/PSI Chemical Thermodynamic Data Base has been updated to support performance assessments of the planned Swiss repositories for radioactive waste. The update from version $05 / 92$ to $01 / 01$ involved major revisions for most of the actinides and fission products. Altogether, more than $70 \%$ of the database contents have been revised. Data for $\mathrm{U}, \mathrm{Np}, \mathrm{Pu}, \mathrm{Am}$ and Tc recommended by the NEA TDB project were considered in the update. Thermodynamic data for Th, Sn, Eu, Pd, Al, and solubility and metal complexation of sulphides and silicates were extensively reviewed. Data for $\mathrm{Zr}$, Ni and Se were examined less rigorously as these elements are currently being reviewed in phase II of the NEA TDB project. Our experiences from this two year team effort can be summarised as follows. Detailed in-house reviews and critical appraisal of NEA recommendations greatly improved the chemical consistency and quality of the selected data. On the other hand, we could discern major gaps in the data, especially missing carbonate complexes. In some systems, e.g. $\mathrm{Th}(\mathrm{IV})-\mathrm{H}_{2} \mathrm{O}$ and $\mathrm{U}(\mathrm{IV})-\mathrm{H}_{2} \mathrm{O}$, experimental data could not be described by a unique set of thermodynamic constants. There, a pragmatic approach based on solubility data was chosen for application to performance assessment. The electronic version of our database and information concerning its full documentation is available on our PSI web site (http://www.psi.ch/les).

\section{Introduction}

Equilibrium thermodynamics is one of the pillars which support safety analyses of repositories for radioactive waste. Thermodynamic constants are used in modelling reference pore waters, calculating radionuclide solubility limits, deriving case specific sorption coefficients, and last but not least in analysing experimental results. It is important to use the same database in all instances of this model chain to guarantee internally consistent results.

The original Nagra Thermochemical Data Base, issued in 1991 [1] and 1992 [2], was based on data reviews and experimental studies published through 1990. The Nagra/PSI Chemical Thermodynamic Data Base has now been updated to support performance assessments of the planned Swiss repositories for radioactive waste [3]. Database version

\footnotetext{
*Author for correspondence (E-mail: wolfgang.hummel@psi.ch).
}

05/92 [2] distinguished two types of data, "core data" and "supplemental data". Core data are for elements commonly found as major solutes in natural waters. These data are well established and have not been changed to any significant degree in this update. Supplemental data comprise actinides and fission products, $\mathrm{Mn}, \mathrm{Fe}, \mathrm{Si}$ and $\mathrm{Al}$. Our update from version $05 / 92$ [2] to $01 / 01$ [3] involved major revisions for most of the supplemental data. All together, more than $70 \%$ of our data base contents have been updated.

Data for $\mathrm{U}, \mathrm{Np}, \mathrm{Pu}, \mathrm{Am}$ and $\mathrm{Tc}$ recommended by the NEA TDB project [4-7] were considered in our update. Our reasons for not accepting all NEA recommendations are documented in detail [3]. Thermodynamic data for Th, Sn, $\mathrm{Eu}, \mathrm{Pd}, \mathrm{Al}$, and solubility and metal complexation of sulphides and silicates were extensively reviewed [3]. Data for $\mathrm{Zr}, \mathrm{Ni}$ and Se were examined less rigorously as these elements are being reviewed in phase II of the NEA TDB project.

It should be mentioned that unlike most other database updates, ours [3] includes fewer compounds and complexes than the original version [2]. This is the result of efforts to discharge ballast, i.e. to remove data for highly soluble salts, and hypothetical, questionable or completely irrelevant compounds and complexes. In addition, data of questionable quality have been removed.

This report summarises our observations from this two year team effort. Briefly, these are: (1) Detailed in-house reviews and critical appraisal of NEA recommendations greatly improved the chemical consistency and quality of the selected data, as shown by comparison of complexation constants for M(III) (Eu, Am, Pu) and M(IV) (Sn, Zr, Th, $\mathrm{U}, \mathrm{Np}, \mathrm{Pu}$ ) oxidation states of actinides and fission products. (2) In some systems, e.g. $\mathrm{ThO}_{2}-\mathrm{H}_{2} \mathrm{O}$ and $\mathrm{UO}_{2}-\mathrm{H}_{2} \mathrm{O}$, we encountered conflicting data, i.e. the experimental data could not be described by a unique set of thermodynamic constants. In these cases, a pragmatic approach based on solubility data was chosen for application to performance assessment. (3) In some cases we included uncertain data as guidelines for modellers. (4) We could discern major gaps in the data, especially missing carbonate complexes. (5) Finally, future data needs were identified.

\section{Chemical consistency of selected thermodynamic data}

The magnitudes of equilibrium constants of aqueous complexes and solids are expected to reveal characteristic Brought to you by | Lib4RI Eawag-Empa

Authenticated 
patterns when different groups of metals and ligands are compared. Some overall patterns can be deduced from the position of the element in the periodic table (i.e. principal element groups, Irving-Williams series of transition metals, lanthanide systematics). Many empirical and semi-empirical correlations have been discussed in the literature relating aqueous complex and solid formation constants to various parameters, e.g. ionisation potentials, electronegativity, charge/radius ratios, protonation constants [8]. They are important for qualitative appraisal of new data and may be used to estimate constants that are unknown or difficult to access by experimental means $[9,10]$.

We did not use such correlations in our present update to estimate formation constants in any systematic way. The selection of updated constants is almost exclusively based on experimental findings. Therefore, chemical patterns and correlations revealed in our selected data may serve as an independent measure of the chemical consistency of the database.

\subsection{A first look at groups of metals and ligands}

Comparing equilibrium constants of cations of the same charge and comparable ionic radii is the obvious first step in exploring the overall chemical consistency of a database.

Complex formation constants of tetravalent actinides, $\mathrm{Zr}^{4+}$ and $\mathrm{Sn}^{4+}$ are summarised in Table 1 . The $\log _{10} K$ patterns in Table 1 reveal that our data selected for tetravalent metals are consistent from a chemical point of view and none of the formation constants seems to be grossly wrong. Note the well known phenomenon that the data for Th(IV) deviate considerably from the other M(IV) actinide ions. For fluoride and hydroxide complexes this can be rationalised in terms of ionic radii (see Sect. 2.3 and Figs. 1 and 2). Lack of experimental data or of experimental data of sufficient quality to pass our review resulted in some gaps in Table 1 . However, considering the good overall consistency

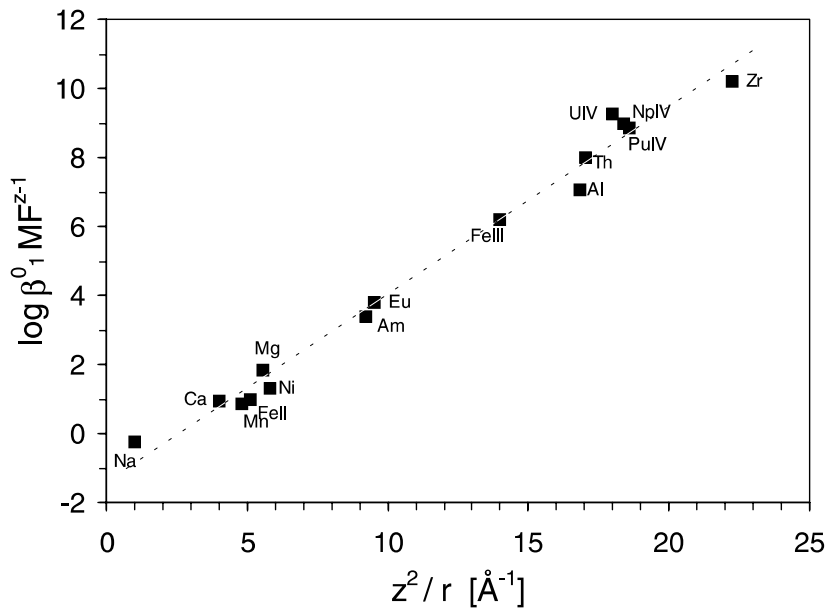

Fig. 1. Correlation between ionic index $\left(z^{2} / r\right.$, square of formal charge divided by ionic radius [13]) and $\log _{10} \beta_{1}{ }^{\circ}$ for the monofluoride complexes of hard cations and $\mathrm{Ni}(\mathrm{II})$.

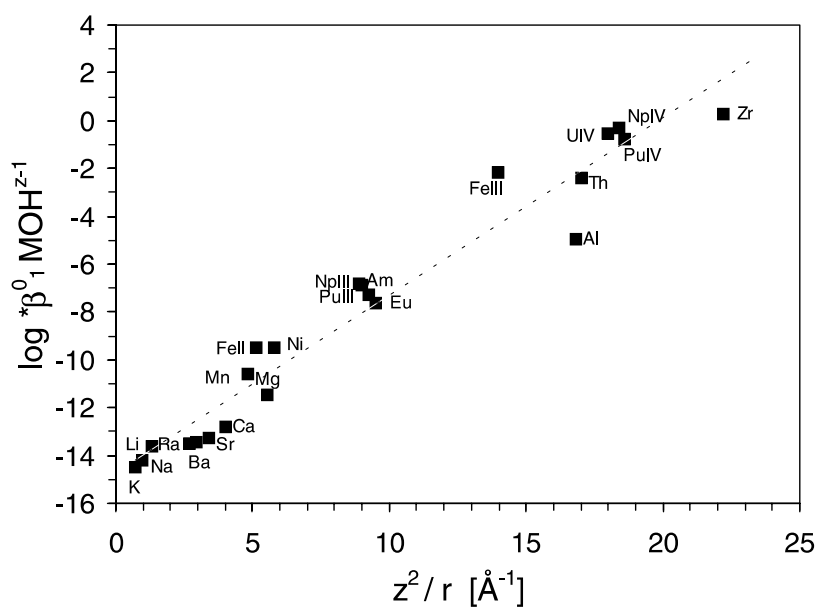

Fig. 2. Correlation between ionic index $\left(z^{2} / r\right.$, square of formal charge divided by ionic radius [13]) and $\log _{10} \beta_{1}{ }^{\circ}$ for the monohydroxo complexes of hard cations and $\mathrm{Ni}(\mathrm{II})$.
Table 1. M(IV) compounds and complexes. For clarity, rounded values without uncertainty ranges are presented here.

\begin{tabular}{|c|c|c|c|c|c|c|}
\hline \multirow[b]{2}{*}{$\mathrm{M}^{4+}$ complexes and solids } & \multirow[b]{2}{*}{$\mathrm{Th}^{4+}$} & \multirow[b]{2}{*}{$\mathrm{U}^{4+}$} & \multicolumn{2}{|c|}{$\log _{10} \beta^{\circ}$} & \multirow[b]{2}{*}{$\mathrm{Zr}^{4+}$} & \multirow[b]{2}{*}{$\mathrm{Sn}^{4+}$} \\
\hline & & & $\mathrm{Np}^{4+}$ & $\mathrm{Pu}^{4+}$ & & \\
\hline $\begin{array}{l}\mathrm{MO}_{2}(\mathrm{cr})+2 \mathrm{H}_{2} \mathrm{O} \Leftrightarrow \mathrm{M}(\mathrm{OH})_{4}(\mathrm{aq}) \\
\mathrm{MO}_{2}(\mathrm{~s})+2 \mathrm{H}_{2} \mathrm{O} \Leftrightarrow \mathrm{M}(\mathrm{OH})_{4}(\mathrm{aq})\end{array}$ & -8.5 & -9 & -8.3 & -10.4 & -11.6 & $\begin{array}{l}-8.0 \\
-7.3 \\
\end{array}$ \\
\hline $\begin{array}{l}\mathrm{M}^{4+}+\mathrm{H}_{2} \mathrm{O} \Leftrightarrow \mathrm{MOH}^{3+}+\mathrm{H}^{+} \\
\mathrm{M}^{4+}+4 \mathrm{H}_{2} \mathrm{O} \Leftrightarrow \mathrm{M}(\mathrm{OH})_{4}(\mathrm{aq})+4 \mathrm{H}^{+} \\
\mathrm{M}(\mathrm{OH})_{4}(\mathrm{aq})+\mathrm{H}_{2} \mathrm{O} \Leftrightarrow \mathrm{M}(\mathrm{OH})_{5}{ }^{-}+\mathrm{H}^{+} \\
\end{array}$ & $\begin{array}{r}-2.4 \\
-18.4\end{array}$ & $\begin{array}{l}-0.5 \\
-9\end{array}$ & $\begin{array}{l}-0.3 \\
-9.8\end{array}$ & $\begin{array}{l}-0.8 \\
-8.4\end{array}$ & $\begin{array}{r}0.3 \\
-9.7 \\
-6.3 \\
\end{array}$ & -8.0 \\
\hline $\begin{array}{l}\mathrm{M}^{4+}+4 \mathrm{CO}_{3}{ }^{2-} \Leftrightarrow \mathrm{M}\left(\mathrm{CO}_{3}\right)_{4}{ }^{4-} \\
\mathrm{M}^{4+}+5 \mathrm{CO}_{3}{ }^{2-} \Leftrightarrow \mathrm{M}\left(\mathrm{CO}_{3}\right)_{5}{ }^{6-} \\
\mathrm{M}^{4+}+\mathrm{CO}_{3}{ }^{2-}+3 \mathrm{H}_{2} \mathrm{O} \Leftrightarrow \mathrm{M}\left(\mathrm{CO}_{3}\right)(\mathrm{OH})_{3}{ }^{-}+3 \mathrm{H}^{+}\end{array}$ & $\begin{array}{r}29.8 \\
-3.1 \\
\end{array}$ & $\begin{array}{l}35.2 \\
34.1\end{array}$ & $\begin{array}{l}36.7 \\
35.6\end{array}$ & $\begin{array}{l}35.9 \\
34.5\end{array}$ & & \\
\hline $\begin{array}{l}\mathrm{M}^{4+}+\mathrm{SO}_{4}{ }^{2-} \Leftrightarrow \mathrm{MSO}_{4}{ }^{2+} \\
\mathrm{M}^{4+}+2 \mathrm{SO}_{4}{ }^{2-} \Leftrightarrow \mathrm{M}\left(\mathrm{SO}_{4}\right)_{2}(\mathrm{aq})\end{array}$ & $\begin{array}{r}7.6 \\
11.6 \\
\end{array}$ & $\begin{array}{r}6.6 \\
10.5 \\
\end{array}$ & $\begin{array}{r}6.9 \\
11.1 \\
\end{array}$ & $\begin{array}{r}6.9 \\
11.1 \\
\end{array}$ & 7.0 & \\
\hline $\mathrm{M}^{4+}+\mathrm{HPO}_{4}{ }^{2-} \Leftrightarrow \mathrm{MHPO}_{4}{ }^{2+}$ & 13 & & & & & \\
\hline $\begin{array}{l}\mathrm{M}^{4+}+\mathrm{F}^{-} \Leftrightarrow \mathrm{MF}^{3+} \\
\mathrm{M}^{4+}+2 \mathrm{~F}^{-} \Leftrightarrow \mathrm{MF}_{2}{ }^{2+} \\
\mathrm{M}^{4+}+3 \mathrm{~F}^{-} \Leftrightarrow \mathrm{MF}_{3}^{+} \\
\mathrm{M}^{4+}+4 \mathrm{~F}^{-} \Leftrightarrow \mathrm{MF}_{4}(\mathrm{aq})\end{array}$ & $\begin{array}{r}8.0 \\
14.2 \\
18.9 \\
22.3\end{array}$ & $\begin{array}{r}9.3 \\
16.2 \\
21.6 \\
25.6\end{array}$ & $\begin{array}{r}9.0 \\
15.7\end{array}$ & $\begin{array}{r}8.8 \\
15.7\end{array}$ & $\begin{array}{l}10.2 \\
18.5 \\
24.7 \\
30.1\end{array}$ & \\
\hline $\mathrm{M}^{4+}+\mathrm{Cl}^{-} \Leftrightarrow \mathrm{MCl}^{3+}$ & & 1.7 & 1.5 & 1.8 & 1.5 & \\
\hline
\end{tabular}


Table 2. M(III) compounds and complexes. For clarity, rounded values without uncertainty ranges are presented here.

\begin{tabular}{|c|c|c|c|c|}
\hline \multirow[b]{2}{*}{$\mathrm{M}^{3+}$ complexes and solids } & \multicolumn{4}{|c|}{$\log _{10} \beta^{\circ}$} \\
\hline & $\mathrm{Np}^{3+}$ & $\mathrm{Pu}^{3+}$ & $\mathrm{Am}^{3+}$ & $\mathrm{Eu}^{3+}$ \\
\hline $\begin{array}{l}\mathrm{M}(\mathrm{OH})_{3}(\mathrm{cr})+3 \mathrm{H}^{+} \Leftrightarrow \mathrm{M}^{3+}+3 \mathrm{H}_{2} \mathrm{O} \\
\mathrm{M}(\mathrm{OH})_{3}(\mathrm{am})+3 \mathrm{H}^{+} \Leftrightarrow \mathrm{M}^{3+}+3 \mathrm{H}_{2} \mathrm{O} \\
\mathrm{M}_{2}(\mathrm{CO})_{3}(\mathrm{cr}) \Leftrightarrow 2 \mathrm{M}^{3+}+3 \mathrm{CO}_{3}{ }^{2-} \\
\mathrm{M}(\mathrm{OH})_{\mathrm{CO}_{3}}(\mathrm{cr}) \Leftrightarrow \mathrm{M}^{3+}+\mathrm{OH}^{-}+\mathrm{CO}_{3}{ }^{2-}\end{array}$ & & 15.8 & $\begin{array}{r}15.2 \\
17.0 \\
-33.4 \\
-21.2\end{array}$ & $\begin{array}{r}14.9 \\
17.6 \\
-35.0 \\
-21.7\end{array}$ \\
\hline $\begin{array}{l}\mathrm{M}^{3+}+\mathrm{H}_{2} \mathrm{O} \Leftrightarrow \mathrm{MOH}^{2+}+\mathrm{H}^{+} \\
\mathrm{M}^{3+}+2 \mathrm{H}_{2} \mathrm{O} \Leftrightarrow \mathrm{M}(\mathrm{OH})_{2}^{+}+2 \mathrm{H}^{+} \\
\mathrm{M}^{3+}+3 \mathrm{H}_{2} \mathrm{O} \Leftrightarrow \mathrm{M}(\mathrm{OH})_{3}(\mathrm{aq})+3 \mathrm{H}^{+} \\
\mathrm{M}^{3+}+4 \mathrm{H}_{2} \mathrm{O} \Leftrightarrow \mathrm{M}(\mathrm{OH})_{4}^{-}+4 \mathrm{H}^{+}\end{array}$ & -6.8 & -6.9 & $\begin{array}{r}-7.3 \\
-15.2 \\
-25.7\end{array}$ & $\begin{array}{r}-7.6 \\
-15.1 \\
-23.7 \\
-36.2\end{array}$ \\
\hline $\begin{array}{l}\mathrm{M}^{3+}+\mathrm{CO}_{3}{ }^{2-} \Leftrightarrow \mathrm{MCO}_{3}{ }^{+} \\
\mathrm{M}^{3+}+2 \mathrm{CO}_{3}{ }^{2-} \Leftrightarrow \mathrm{M}\left(\mathrm{CO}_{3}\right)_{2}{ }^{-} \\
\mathrm{M}^{3+}+3 \mathrm{CO}_{3}{ }^{2-} \Leftrightarrow \mathrm{M}\left(\mathrm{CO}_{3}\right)_{3}{ }^{3-}\end{array}$ & & & $\begin{array}{r}7.8 \\
12.3 \\
15.2\end{array}$ & $\begin{array}{r}8.1 \\
12.1\end{array}$ \\
\hline $\begin{array}{l}\mathrm{M}^{3+}+\mathrm{SO}_{4}{ }^{2-} \Leftrightarrow \mathrm{MSO}_{4}{ }^{+} \\
\mathrm{M}^{3+}+2 \mathrm{SO}_{4}{ }^{2-} \Leftrightarrow \mathrm{M}\left(\mathrm{SO}_{4}\right)_{2}{ }^{-}\end{array}$ & & $\begin{array}{l}3.9 \\
5.7\end{array}$ & $\begin{array}{l}3.9 \\
5.4\end{array}$ & $\begin{array}{l}4.0 \\
5.7\end{array}$ \\
\hline $\mathrm{M}^{3+}+\mathrm{HPO}_{4}^{2-} \Leftrightarrow \mathrm{MHPO}_{4}^{+}$ & & & 3.0 & \\
\hline $\begin{array}{l}\mathrm{M}^{3+}+\mathrm{F}^{-} \Leftrightarrow \mathrm{MF}^{2+} \\
\mathrm{M}^{3+}+2 \mathrm{~F}^{-} \Leftrightarrow \mathrm{MF}_{2}^{+}\end{array}$ & & & $\begin{array}{l}3.4 \\
5.8\end{array}$ & $\begin{array}{l}3.8 \\
6.5\end{array}$ \\
\hline $\begin{array}{l}\mathrm{M}^{3+}+\mathrm{Cl}^{-} \Leftrightarrow \mathrm{MCl}^{2+} \\
\mathrm{M}^{3+}+2 \mathrm{Cl}^{-} \Leftrightarrow \mathrm{MCl}_{2}^{+}\end{array}$ & & 1.2 & 1.1 & $\begin{array}{l}1.1 \\
1.5\end{array}$ \\
\hline $\mathrm{M}^{3+}+\mathrm{SiO}(\mathrm{OH})_{3}{ }^{-} \Leftrightarrow \mathrm{MSiO}(\mathrm{OH})_{3}{ }^{2+}$ & & & 8.1 & 7.9 \\
\hline
\end{tabular}

of these data, Table 1 can be used to estimate limiting values of missing constants for specific applications. The mixed hydroxide carbonate complexes of $\mathrm{U}^{4+}, \mathrm{Np}^{4+}$ and $\mathrm{Pu}^{4+}$ are of particular interest in modelling exercises as they may be the dominant species in carbonate rich ground waters, but practically no experimental data are available to derive reliable constants. For application in the ongoing Nagra performance assessment we estimated limiting values [28] but these numbers are not included in the Nagra/PSI Chemical Thermodynamic Data Base 01/01.

As expected from a chemical point of view, the equilibrium constants for $\mathrm{Am}^{3+}$ and $\mathrm{Eu}^{3+}$ solids and aqueous species are very similar (Table 2). Data for $\mathrm{Np}^{3+}$ and $\mathrm{Pu}^{3+}$ are almost absent and appraisal of chemical consistency is hardly possible although the few formation constants for $\mathrm{Pu}^{3+}$ fit well with the $\mathrm{Am}^{3+}$ and $\mathrm{Eu}^{3+}$ data. A similar picture of chemical consistency is observed comparing the hexavalent dioxo cations of $\mathrm{U}, \mathrm{Np}$ and $\mathrm{Pu}$ (Table 3 ). The overall consistent pattern of all available data could be used to estimate limiting values of missing constants for specific applications.

\subsection{Chemical patterns based on periodic properties of the elements}

The internal geochemical consistency of the selected thermodynamic constants can further be tested with the help of well-known empirical rules related to periodic properties of the elements. One of the most popular and useful schemes for the semi-quantitative prediction of stability constants is that of classifying cations and ligands into "hard" and "soft" (or 'A' and 'B') groups (see [11, 12] and Fig. III.7 in [8]). The stability of metal complexes and solid compounds with ionic bonding character ("hard" or ' $A$ ' metals) increases with decreasing cation radius and increasing charge. In addition, the well-established series of acid dissociation constants can be used as an additional guide to predict the sequence of complex stability for a given metal [11]. The $\mathrm{p} K_{\mathrm{a}}{ }^{\circ}$ values of these acids may be regarded as formation constants of the proton (a hard cation) with the anions (ligands) of these acids. From the sequence of increasing $\mathrm{p} K_{\mathrm{a}}^{\circ}$, i.e.

$$
\begin{aligned}
& \mathrm{Cl}^{-}<\mathrm{NO}_{3}{ }^{-}<\mathrm{SO}_{4}{ }^{2-}<\mathrm{H}_{2} \mathrm{PO}_{4}{ }^{-}<\mathrm{F}^{-}<\mathrm{HCO}_{3}{ }^{-} \\
& <\mathrm{HPO}_{4}{ }^{2-}<\mathrm{SiO}(\mathrm{OH})_{3}{ }^{-}<\mathrm{CO}_{3}{ }^{2-}<\mathrm{PO}_{4}{ }^{3-}<\mathrm{OH}^{-}
\end{aligned}
$$

the sequence of stability constants for complexes of other hard cations can be predicted by analogy.

In Table 4 the $\log _{10} K$ values of the constants included in the database for mononuclear single ligand complexes are listed in a matrix structure for all metals with hard or borderline character. The purpose of this table is to give a compact "panoramic view" of the selected thermodynamic data. The cations are listed in order of increasing ionic charge and decreasing ionic radius (from left to right) and the ligands in order of increasing softness (from top to bottom). Therefore, constants for hard metals are expected to increase from left to right along rows and to decrease from top to bottom along columns. Whenever a significant anomaly in the expected order appears, the number is highlighted. The table therefore gives a quick overview of the internal consistency of the selected thermodynamic data and allows identification of major anomalies.

In general, the constants follow the predicted trend and increase along rows. Note also that the constants for metal silicate complexes fit very well in the relative order of ligand stability, although they have been classified as "uncertain data" (see Sect. 4) because of ambiguities concerning the stoichiometry of the complexes. $\mathrm{Mg}, \mathrm{Al}$ and $\mathrm{Mn}$ do not folBrought to you by | Lib4RI Eawag-Empa Authenticated 
Table 3. M(VI)-dioxo complexes and solids. For clarity, rounded values without uncertainty ranges are presented here.

\begin{tabular}{|c|c|c|c|}
\hline $\mathrm{MO}_{2}^{2+}$ complexes and solids & $\mathrm{UO}_{2}^{2+}$ & $\begin{array}{l}\log _{10} \beta^{\circ} \\
\mathrm{NpO}_{2}{ }^{2+}\end{array}$ & $\mathrm{PuO}_{2}{ }^{2+}$ \\
\hline $\begin{array}{l}\mathrm{MO}_{2}{ }^{2+}+2 \mathrm{H}_{2} \mathrm{O} \Leftrightarrow \mathrm{MO}_{2}(\mathrm{OH})_{2}(\mathrm{~s})+2 \mathrm{H}^{+} \\
\mathrm{MO}_{2}{ }^{2+}+\mathrm{CO}_{3}{ }^{2-} \Leftrightarrow \mathrm{MO}_{2} \mathrm{CO}_{3}(\mathrm{~s})\end{array}$ & $\begin{array}{r}-6.0 \\
14.5\end{array}$ & $\begin{array}{r}-5.5 \\
14.6\end{array}$ & $\begin{array}{r}-5.5 \\
14.2\end{array}$ \\
\hline $\begin{array}{l}\mathrm{MO}_{2}{ }^{2+}+\mathrm{H}_{2} \mathrm{O} \Leftrightarrow \mathrm{MO}_{2} \mathrm{OH}^{+}+\mathrm{H}^{+} \\
\mathrm{MO}_{2}{ }^{2+}+2 \mathrm{H}_{2} \mathrm{O} \Leftrightarrow \mathrm{MO}_{2}(\mathrm{OH})_{2}(\mathrm{aq})+2 \mathrm{H}^{+} \\
\mathrm{MO}_{2}{ }^{2+}+3 \mathrm{H}_{2} \mathrm{O} \Leftrightarrow \mathrm{MO}_{2}(\mathrm{OH})_{3}{ }^{-}+3 \mathrm{H}^{+} \\
\mathrm{MO}_{2}{ }^{2+}+4 \mathrm{H}_{2} \mathrm{O} \Leftrightarrow \mathrm{MO}_{2}(\mathrm{OH})_{4}{ }^{2-}+4 \mathrm{H}^{+} \\
2 \mathrm{MO}_{2}{ }^{2+}+\mathrm{H}_{2} \mathrm{O} \Leftrightarrow\left(\mathrm{MO}_{2}\right)_{2} \mathrm{OH}^{3+}+\mathrm{H}^{+} \\
2 \mathrm{MO}_{2}{ }^{2+}+2 \mathrm{H}_{2} \mathrm{O} \Leftrightarrow\left(\mathrm{MO}_{2}\right)_{2}(\mathrm{OH})_{2}{ }^{2+}+2 \mathrm{H}^{+} \\
3 \mathrm{MO}_{2}{ }^{2+}+4 \mathrm{H}_{2} \mathrm{O} \Leftrightarrow\left(\mathrm{MO}_{2}\right)_{3}(\mathrm{OH})_{4}{ }^{2+}+4 \mathrm{H}^{+} \\
3 \mathrm{MO}_{2}{ }^{2+}+5 \mathrm{H}_{2} \mathrm{O} \Leftrightarrow\left(\mathrm{MO}_{2}\right)_{3}(\mathrm{OH})_{5}{ }^{+}+5 \mathrm{H}^{+} \\
3 \mathrm{MO}_{2}{ }^{2+}+7 \mathrm{H}_{2} \mathrm{O} \Leftrightarrow\left(\mathrm{MO}_{2}\right)_{3}(\mathrm{OH})_{7}+7 \mathrm{H}^{+} \\
4 \mathrm{MO}_{2}{ }^{2+}+7 \mathrm{H}_{2} \mathrm{O} \Leftrightarrow\left(\mathrm{MO}_{2}\right)_{4}(\mathrm{OH})_{7}{ }^{+}+7 \mathrm{H}^{+}\end{array}$ & $\begin{array}{l}-5.2 \\
-12 \\
-19.2 \\
-33 \\
-2.7 \\
-5.6 \\
-11.9 \\
-15.6 \\
-31 \\
-21.9\end{array}$ & $\begin{array}{l}-5.1 \\
-19 \\
-33 \\
-6.3 \\
-17.1\end{array}$ & $\begin{array}{l}-5.5 \\
-13\end{array}$ \\
\hline $\begin{array}{l}\mathrm{MO}_{2}{ }^{2+}+\mathrm{CO}_{3}{ }^{2-} \Leftrightarrow \mathrm{MO}_{2} \mathrm{CO}_{3}(\mathrm{aq})^{2-} \\
\mathrm{MO}_{2}{ }^{2+}+2 \mathrm{CO}_{3}{ }^{2-} \Leftrightarrow \mathrm{MO}_{2}\left(\mathrm{CO}_{3}\right)_{2}{ }^{2-} \\
\mathrm{MO}_{2}{ }^{2+}+3 \mathrm{CO}_{3}{ }^{2-} \Leftrightarrow \mathrm{MO}_{2}\left(\mathrm{CO}_{3}\right)_{3}{ }^{2-} \\
3 \mathrm{MO}_{2}{ }^{2+}+6 \mathrm{CO}_{3}^{2-} \Leftrightarrow\left(\mathrm{MO}_{2}\right)_{3}\left(\mathrm{CO}_{3}\right)_{6}{ }^{6-} \\
2 \mathrm{MO}_{2}{ }^{2+}+\mathrm{CO}_{3}{ }^{2-}+3 \mathrm{H}_{2} \mathrm{O} \Leftrightarrow\left(\mathrm{MO}_{2}\right)_{2}(\mathrm{OH})_{3} \mathrm{CO}_{3}{ }^{-}+3 \mathrm{H}^{+} \\
3 \mathrm{MO}_{2}{ }^{2+}+\mathrm{CO}_{3}{ }^{2-}+3 \mathrm{H}_{2} \mathrm{O} \Leftrightarrow\left(\mathrm{MO}_{2}\right)_{3}(\mathrm{OH})_{3} \mathrm{CO}_{3}{ }^{+}+3 \mathrm{H}^{+}\end{array}$ & $\begin{array}{c}9.7 \\
16.9 \\
21.6 \\
54 \\
-0.9 \\
0.7\end{array}$ & $\begin{array}{r}9.3 \\
16.5 \\
19.4 \\
49.8 \\
-2.9\end{array}$ & $\begin{array}{r}9.3 \\
14.6 \\
17.7\end{array}$ \\
\hline $\begin{array}{l}\mathrm{MO}_{2}{ }^{2+}+\mathrm{SO}_{4}{ }^{2-} \Leftrightarrow \mathrm{MO}_{2} \mathrm{SO}_{4}(\mathrm{aq}) \\
\mathrm{MO}_{2}{ }^{2+}+2 \mathrm{SO}_{4}{ }^{2-} \Leftrightarrow \mathrm{MO}_{2}\left(\mathrm{SO}_{4}\right)_{2}{ }^{2-}\end{array}$ & $\begin{array}{l}3.2 \\
4.1\end{array}$ & $\begin{array}{l}3.3 \\
4.7\end{array}$ & $\begin{array}{l}3.4 \\
4.4\end{array}$ \\
\hline $\begin{array}{l}\mathrm{MO}_{2}^{2+}+\mathrm{Cl}^{-} \Leftrightarrow \mathrm{MO}_{2} \mathrm{Cl}^{+} \\
\mathrm{MO}_{2}^{2+}+2 \mathrm{Cl}^{-} \Leftrightarrow \mathrm{MO}_{2}(\mathrm{Cl})_{2}(\mathrm{aq})\end{array}$ & $\begin{array}{r}0.2 \\
-1.1\end{array}$ & 0.4 & $\begin{array}{r}0.7 \\
-0.6\end{array}$ \\
\hline $\begin{array}{l}\mathrm{MO}_{2}{ }^{2+}+\mathrm{F}^{-} \Leftrightarrow \mathrm{MO}_{2} \mathrm{~F}^{+} \\
\mathrm{MO}_{2}{ }^{2+}+2 \mathrm{~F}^{-} \Leftrightarrow \mathrm{MO}_{2} \mathrm{~F}_{2}(\mathrm{aq}) \\
\mathrm{MO}_{2}{ }^{2+}+3 \mathrm{~F}^{-} \Leftrightarrow \mathrm{MO}_{2} \mathrm{~F}_{3}- \\
\mathrm{MO}_{2}{ }^{2+}+4 \mathrm{~F}^{-} \Leftrightarrow \mathrm{MO}_{2} \mathrm{~F}_{4}{ }^{2-}\end{array}$ & $\begin{array}{r}5.1 \\
8.6 \\
10.9 \\
11.7\end{array}$ & $\begin{array}{l}4.6 \\
7.6\end{array}$ & $\begin{array}{l}4.6 \\
7.3\end{array}$ \\
\hline $\mathrm{MO}_{2}{ }^{2+}+\mathrm{NO}_{3}{ }^{-} \Leftrightarrow \mathrm{MO}_{2} \mathrm{NO}_{3}{ }^{+}$ & 0.3 & & \\
\hline $\begin{array}{l}\mathrm{MO}_{2}{ }^{2+}+\mathrm{PO}_{4}{ }^{3-} \Leftrightarrow \mathrm{MO}_{2} \mathrm{PO}_{4}{ }^{-} \\
\mathrm{MO}_{2}{ }^{2+}+\mathrm{HPO}_{4}{ }^{2-} \Leftrightarrow \mathrm{MO}_{2} \mathrm{HPO}_{4}(\mathrm{aq}) \\
\mathrm{MO}_{2}{ }^{2+}+\mathrm{H}_{2} \mathrm{PO}_{4}-\Leftrightarrow \mathrm{MO}_{2} \mathrm{H}_{2} \mathrm{PO}_{4}{ }^{+} \\
\mathrm{MO}_{2}{ }^{2+}+\mathrm{H}_{3} \mathrm{PO}_{4}(\mathrm{aq}) \Leftrightarrow \mathrm{MO}_{2} \mathrm{H}_{3} \mathrm{PO}_{4}{ }^{2+} \\
\mathrm{MO}_{2}{ }^{2+}+2 \mathrm{H}_{2} \mathrm{PO}_{4}{ }^{-} \Leftrightarrow \mathrm{MO}_{2}\left(\mathrm{H}_{2} \mathrm{PO}_{4}\right)_{2}(\mathrm{aq}) \\
\mathrm{MO}_{2}{ }^{2+}+2 \mathrm{H}_{3} \mathrm{PO}_{4}(\mathrm{aq}) \Leftrightarrow \mathrm{MO}_{2} \mathrm{H}_{2}\left(\mathrm{H}_{2} \mathrm{PO}_{4}\right)_{2}{ }^{+}+\mathrm{H}^{+} \\
\mathrm{MO}_{2}{ }^{2+}+2 \mathrm{HPO}_{4}{ }^{2-} \Leftrightarrow \mathrm{MO}_{2}\left(\mathrm{HPO}_{4}\right)_{2}{ }^{2-}\end{array}$ & $\begin{array}{r}13.2 \\
7.2 \\
3.2 \\
0.8 \\
4.9 \\
1.7\end{array}$ & $\begin{array}{l}6.2 \\
3.3\end{array}$ & \\
\hline
\end{tabular}

Table 4. Compilation of formation constants $\left(\log _{10} K_{1}{ }^{\circ}\right)$ for single ligand mononuclear complexes included in the updated database. The constants are arranged in order of increasing metal hardness along rows (from left to right) and increasing ligand softness along columns (top to bottom). Constants which do not follow the expected relative order of metal hardness are highlighted in bold face. Values not following the expected order of ligand softness are shown in italics. Only anomalies of more than $0.5 \log$ units are highlighted. The ionic radii are for 6-fold coordination and were taken from [22]. For Mn(II), Fe(II) and Fe(III) the radii for high-spin complexes were selected.

\begin{tabular}{|c|c|c|c|c|c|c|c|c|c|c|c|c|c|c|c|c|c|c|c|c|c|c|}
\hline metals $\rightarrow$ & $\mathbf{K}^{+}$ & $\mathbf{N a}^{+}$ & $\mathbf{L i}^{+}$ & $\mathbf{R a}^{2+}$ & $\mathbf{B a}^{2+}$ & $\mathbf{S r}^{2+}$ & $\mathbf{C a}^{2+}$ & $\mathbf{M n}^{2+}$ & $\mathrm{Fe}^{2+}$ & $\mathbf{M g}^{2+}$ & $\mathbf{N i}^{2+}$ & $\mathbf{N p}^{3+}$ & $\mathbf{P u}^{3+}$ & $\mathbf{A m}^{3+}$ & $\mathbf{E u}^{3+}$ & $\mathrm{Fe}^{3+}$ & $\mathbf{A} \mathbf{l}^{3+}$ & $\mathbf{T h}^{4+}$ & $\mathbf{U}^{4+}$ & $\mathbf{N} \mathbf{p}^{4+}$ & $\mathbf{P u}^{4+}$ & $\mathbf{Z r}^{4+}$ \\
\hline$r[\AA]$ & 1.38 & 1.02 & 0.76 & 1.48 & 1.35 & 1.18 & 1.00 & 0.83 & 0.78 & 0.72 & 0.69 & 1.01 & 1.00 & 0.97 & 0.94 & 0.64 & 0.53 & 0.94 & 0.89 & 0.87 & 0.86 & 0.72 \\
\hline \multicolumn{23}{|l|}{ ligands: } \\
\hline $\mathbf{O H}^{-}$ & -0.5 & -0.2 & 0.4 & 0.5 & 0.5 & 0.7 & 1.2 & 3.4 & 4.5 & 2.6 & 4.5 & 7.2 & 7.1 & 6.7 & 6.4 & 11.8 & 9.1 & 11.6 & 13.5 & 13.7 & 13.2 & 14.3 \\
\hline $\mathrm{PO}_{4}{ }^{3-}$ & - & - & - & - & - & - & - & - & - & - & 8.4 & - & - & - & - & - & - & - & - & - & - & - \\
\hline $\mathrm{CO}_{3}{ }^{2-}$ & - & 1.3 & - & 2.5 & 2.7 & 2.8 & 3.2 & 4.9 & 4.4 & 3.0 & 4.0 & - & - & 7.8 & 8.1 & - & - & - & - & - & - & - \\
\hline $\mathrm{SiO}(\mathrm{OH})_{3}{ }^{-}$ & $-\quad-$ & - & - & - & - & - & 1.2 & - & - & 1.5 & - & - & - & 8.1 & 7.9 & 9.7 & 7.4 & - & - & - & - & - \\
\hline $\mathrm{HPO}_{4}{ }^{2-}$ & - & -0.2 & - & - & - & - & - & - & - & - & 2.9 & - & - & 3.0 & - & - & - & 13 & - & - & - & - \\
\hline $\mathrm{HCO}_{3}^{-}$ & - & -0.3 & - & - & 1.0 & 1.29 & 1.1 & 2.0 & 2.0 & 1.1 & 1 & - & - & - & - & - & - & - & - & - & - & - \\
\hline $\mathbf{F}^{-}$ & - & -0.2 & - & - & - & - & 0.9 & 0.8 & 1.0 & 1.8 & 1.3 & - & - & 3.4 & 3.8 & 6.2 & 7.1 & 8.0 & 9.3 & 9.0 & 8.8 & 0.2 \\
\hline $\mathrm{H}_{2} \mathrm{PO}_{4}{ }^{-}$ & - & - & - & - & - & - & - & - & - & - & 1.5 & - & - & - & - & - & - & - & - & - & - & - \\
\hline $\mathrm{SO}_{4}{ }^{2-}$ & 0.9 & 0.7 & 0.6 & 2.8 & 2.7 & 2.3 & 2.3 & 2.3 & 2.3 & 2.4 & 2.3 & - & 3.9 & 3.9 & 4.0 & 4.0 & 3.9 & 7.6 & 6.6 & 6.9 & 6.9 & 7.0 \\
\hline $\mathrm{NO}_{3}{ }^{-}$ & - & - & - & - & - & - & - & - & - & - & 0.4 & - & - & 1.3 & - & - & - & - & 1.5 & 1.9 & 2.0 & - \\
\hline $\mathrm{Cl}^{-}$ & - & - & - & -0.1 & - & - & - & 0.6 & 0.1 & - & 0.4 & - & 1.2 & 1.1 & 1.1 & 1.5 & - & - & 1.7 & 1.5 & 1.8 & 1.5 \\
\hline
\end{tabular}

low the general trend. The stability constants of $\mathrm{Mg}$ and $\mathrm{Al}$ are well established and thus, their behaviour may indicate the limitation of our simple rule when comparing ' $A$ ' metals $(\mathrm{Mg}, \mathrm{Al})$ and $d$-transition metals $(\mathrm{Fe})$. The data for $\mathrm{Mn}$ need to be thoroughly reviewed before any conclusions can be drawn.

More systematic anomalies appear along columns: (1) Monocarbonato complexes are more stable than monoBrought to you by | Lib4RI Eawag-Empa 
hydroxo complexes (up to $2 \log$ units). This indicates the preferred formation of bidentate carbonate complexes. (2) The monosulphato complexes of alkalis, earth-alkalis and transition metals are more stable than the corresponding monofluoride complexes (by about 1-2 log units). The order reverts to normal for tetravalent actinides. The reason for this behaviour is unclear.

\subsection{Empirical correlations based on charge/size relations}

As a final step, correlations are used to test the consistency of the database. In addition to the elements reviewed in this update [3], some elements are included that have been inherited from the previous version (e.g. $\mathrm{Ca}, \mathrm{Na})[1,2]$.

A convenient way to compare all the hard cations included in the database is plotting their equilibrium constants against the ionic index $\left(z^{2} / r\right.$, [13]). The ionic index allows us to consider the change in stability due to both ionic radius and ionic charge ${ }^{1}$. Therefore, metals of different oxidation state $(+\mathrm{I},+\mathrm{II},+\mathrm{III}$ and $+\mathrm{IV})$ can be included in a single plot. Plots have been prepared for the first hydrolysis constants and formation constants of monofluoride and monosulphate complexes. For all other constants, the data are too sparse to allow a correlation across the whole range of metals.

The plot of formation constants of monofluoride complexes versus the ionic index reveals an excellent correlation (Fig. 1) indicating an overall consistency of the selected fluoride constants.

Fig. 2 shows a reasonably well-defined linear trend for the monohydroxo complexes, from which only the constants of $\mathrm{AlOH}^{2+}$ and $\mathrm{FeOH}^{2+}$ are found to deviate considerably. The $\mathrm{Al}$ and $\mathrm{Fe}(\mathrm{III})$ constants are well-determined, so that it is not possible to ascribe these anomalies to poor data quality. Rather, they reflect a particular chemical behaviour that cannot be rationalised in terms of these simple empirical

\footnotetext{
${ }^{1}$ Slightly different concepts can be found in the literature, e.g. Baes \& Mesmer [29] used the "ion-potential" $z / d$ where $d$ is the metal-oxygen distance.
}



Fig. 3. Correlation between ionic index $\left(z^{2} / r\right.$, square of formal charge divided by ionic radius [13]) and $\log _{10} \beta_{1}^{\circ}$ for the monosulphate complexes of hard cations and $\mathrm{Ni}(\mathrm{II})$. rules. On the other hand, the updated constants for trivalent and tetravalent lanthanides/actinides fit reasonably well in the general trend defined by all the metals.

Finally, although the monosulphate complexes also follow the overall linear trend found for the two former types of constants (Fig. 3) the formation constants of monosulphate species of a given charge seem to be nearly independent of the ionic radius: This is particularly evident in the case of trivalent cations. It is not clear whether this is an artefact due to experimental problems or a specific chemical behaviour of sulphate.

In spite of their empirical nature, the correlations shown in Figs. 1 to 3 indicate a good overall chemical consistency of our database (of course limited to the three types of constants considered). This increases our confidence in the selected data.

\section{Conflicting data}

Parameters describing a particular thermodynamic equilibrium system are derived from experimental quantities obtained by a wide range of methods, e.g. calorimetry, potentiometry, solubility studies. For well studied systems critical examination reveals high quality experimental data that lead to a unique set of thermodynamic constants. The particular equilibrium system is then internally consistent, not only formally but also from a chemical point of view. However, in the course of our reviews we encountered some cases of conflicting experimental data that resisted any attempt to merge them into a unique set of parameters. In the following the conflicting data and our pragmatic solutions are summarised.

In the system $\mathrm{Th}(\mathrm{IV})-\mathrm{H}_{2} \mathrm{O}$ a set of thermodynamic quantities can be derived from experimental data: (1) The hydrolysis constants $\log _{10} \beta_{1}^{\circ}$ and $\log _{10} \beta_{4}^{\circ}$ of $\mathrm{ThOH}^{3+}$ and $\mathrm{Th}(\mathrm{OH})_{4}(\mathrm{aq})$, respectively, have been determined potentiometrically by several authors over a wide range of ionic strength [3]. (2) The thermodynamic properties of $\mathrm{ThO}_{2}$ (cr) have been determined by calorimetry and thus, a solubility product $\log _{10}{ }^{*} K_{s, 0}{ }^{\circ}$ (cr) for $\mathrm{ThO}_{2}(\mathrm{cr})+4 \mathrm{H}^{+} \Leftrightarrow \mathrm{Th}^{4+}+$ $2 \mathrm{H}_{2} \mathrm{O}$ can be derived from the available thermochemical data [14]. (3) Several solubility studies of $\mathrm{ThO}_{2}$ (s) have been reported. However, these solubility studies reveal a very peculiar behaviour of $\mathrm{ThO}_{2}$ (s) and these data cannot be made consistent with the other two data sets.

A synopsis of several solubility studies [14-18] is shown in Fig. 4. At $\mathrm{pH}<5$ the solubility measured at a certain $\mathrm{pH}$ for crystalline $\mathrm{ThO}_{2}$ (cr) differs by orders of magnitude from the solubility of amorphous $\mathrm{ThO}_{2}(\mathrm{am})$ measured at the same $\mathrm{pH}$. At $\mathrm{pH}>6$ both sets of experimental data converge and the solubility of $\mathrm{ThO}_{2}$ (s) becomes independent of $\mathrm{pH}$.

Solubility data for $\mathrm{ThO}_{2}$ (cr) agree fairly well with the solubility predicted by calorimetric data in the range $\mathrm{pH}<3$. On the other hand, solubility data of amorphous $\mathrm{ThO}_{2}(\mathrm{am})$ indicate a solubility product more than 10 orders of magnitude higher than $\mathrm{ThO}_{2}$ (cr) (Fig. 4). In both cases, combining the solubility products $\log _{10}{ }^{*} K_{s, 0}{ }^{\circ}(\mathrm{cr})$ and $\log _{10}{ }^{*} K_{s, 0}{ }^{\circ}(\mathrm{am})$ with the independently determined hydrolysis constant $\log _{10} \beta_{4}{ }^{\circ}$ of $\mathrm{Th}(\mathrm{OH})_{4}$ (aq) results in predicted Th concentrations far from any measured values in neutral and alkaline Brought to you by | Lib4RI Eawag-Empa Authenticated 




Fig. 4. Solubility data of the system Th(IV)$\mathrm{H}_{2} \mathrm{O}$. The thick solid line is calculated using thermodynamic constants selected in this review. Dashed lines represent the estimated uncertainty. The dotted line is calculated using $\log _{10} * K_{s, 0}{ }^{\circ}(\mathrm{am})=12$ derived from $\mathrm{ThO}_{2}(\mathrm{am})$ data $[14,17]$. The thin solid line is calculated using $\log _{10}{ }^{*} K_{s, 0}{ }^{\circ}(\mathrm{cr})=1.8 \mathrm{de}$ rived from $\Delta_{\mathrm{f}} G_{\mathrm{m}}{ }^{\circ}$ of $\mathrm{ThO}_{2}(\mathrm{cr})$ [14]. solutions. In the case of $\mathrm{ThO}_{2}$ (cr) the concentration of dissolved Th(IV) should fall below any detection limit to [Th] $<10^{-16} \mathrm{M}$, whereas for equilibrium with $\mathrm{ThO}_{2}(\mathrm{am})$ concentrations of $[\mathrm{Th}]>10^{-7} \mathrm{M}$ are predicted (see question marks in Fig. 4).

All measured solubility data for $\mathrm{ThO}_{2}(\mathrm{~s})$ at $\mathrm{pH}>6$ have been found in the range $10^{-7} \mathrm{M}>[\mathrm{Th}]>10^{-9} \mathrm{M}$. A mean value of $10^{-8.5} \mathrm{M}$ represents ${ }^{*} K_{s, 4}{ }^{\circ}$ (s) for $\mathrm{ThO}_{2}(\mathrm{~s})+2 \mathrm{H}_{2} \mathrm{O}$ $\Leftrightarrow \mathrm{Th}(\mathrm{OH})_{4}(\mathrm{aq})$. If we combine this constant with the hydrolysis constant $\log _{10} \beta_{4}{ }^{\circ}$ of $\mathrm{Th}(\mathrm{OH})_{4}(\mathrm{aq})$ a solubility product for $\mathrm{ThO}_{2}$ (s) is calculated in between the values for $\mathrm{ThO}_{2}(\mathrm{am})$ and $\mathrm{ThO}_{2}$ (cr) (Fig. 4). This set of parameters now describes the measured solubilities at $\mathrm{pH}>6$ but cannot account for the solubility variation of more than 10 orders of magnitude at lower pH (see question mark in Fig. 4).

The same behaviour is found in the system $\mathrm{U}(\mathrm{IV})-\mathrm{H}_{2} \mathrm{O}$ (Fig. 5). At $\mathrm{pH}<3$ the solubility measured for freshly precipitated $\mathrm{UO}_{2}(\mathrm{am})$ and the solubility of $\mathrm{UO}_{2}(\mathrm{cr})$ derived from calorimetric data differ by 9 orders of magnitude. All measured solubility data for $\mathrm{UO}_{2}(\mathrm{~s})$ at $\mathrm{pH}>5$ have been found in the range $10^{-7} \mathrm{M}>[\mathrm{U}(\mathrm{IV})]>10^{-10} \mathrm{M}$. A mean value of $10^{-9} \mathrm{M}$ represents ${ }^{*} K_{s, 4}{ }^{\circ}$ (s) for $\mathrm{UO}_{2}(\mathrm{~s})+2 \mathrm{H}_{2} \mathrm{O} \Leftrightarrow$ $\mathrm{U}(\mathrm{OH})_{4}(\mathrm{aq})$.

This behaviour is not restricted to Th(IV) and U(IV). Similar patterns have been found for all tetravalent actinides, An(IV). A more detailed discussion and comparison of An(IV) solubility and hydrolysis is given in [19]. These authors conclude from the solubility data measured for $\mathrm{ThO}_{2}$ (cr) and $\mathrm{UO}_{2}$ (cr) that the crystalline dioxide is the solubility limiting solid only at very low $\mathrm{pH}$, where $\mathrm{An}^{4+}$ is the predominant aqueous species. They postulate that the bulk crystalline dioxide must be covered with an amorphous surface layer as soon as the $\mathrm{An}^{4+}$ ion undergoes hydrolysis reactions, and the dissolution of $\mathrm{AnO}_{2}$ (cr) seems to become quasi-irreversible. According to [19] further investigations are needed to verify this hypothesis and to ascertain the chemical form of the solubility limiting solid in natural systems. Despite this promising qualitative model, we have to conclude that at present the systems $\mathrm{ThO}_{2}-\mathrm{H}_{2} \mathrm{O}$ and $\mathrm{UO}_{2}-\mathrm{H}_{2} \mathrm{O}$ are NOT understood in terms of quantitative equilibrium thermodynamics. The experimental data sets cannot be described by a consistent quantitative model without ad hoc assumptions.

As a pragmatic solution of this dilemma, we decided to rely on measured solubilities of Th(IV) and U(IV) in neutral and alkaline solutions. Hence, the thermodynamic constants selected for our database update (Table 1, [3]) do not refer to well defined thorianite, $\mathrm{ThO}_{2}$ (cr), and uraninite, $\mathrm{UO}_{2}$ (cr), used in calorimetric measurements but to the still poorly defined solids $\mathrm{ThO}_{2}(\mathrm{~s})$ and $\mathrm{UO}_{2}$ (s) encountered in solubility studies. Furthermore, we considered independently determined hydrolysis constants in the case of Th, and adjusted the missing hydrolysis constant of $\mathrm{U}(\mathrm{OH})_{4}(\mathrm{aq})$ in such a way that it is compatible with all experimental solubility measurements in the system $\mathrm{UO}_{2}(\mathrm{~s})-\mathrm{H}_{2} \mathrm{O}-\mathrm{CO}_{2}$ above $\mathrm{pH} 4$. Consequently, the thermodynamic constants selected in this review [3] cannot be used to represent the widely varying solubilities of $\mathrm{ThO}_{2}$ and $\mathrm{UO}_{2}$ at low $\mathrm{pH}$.

Brought to you by | Lib4RI Eawag-Empa 


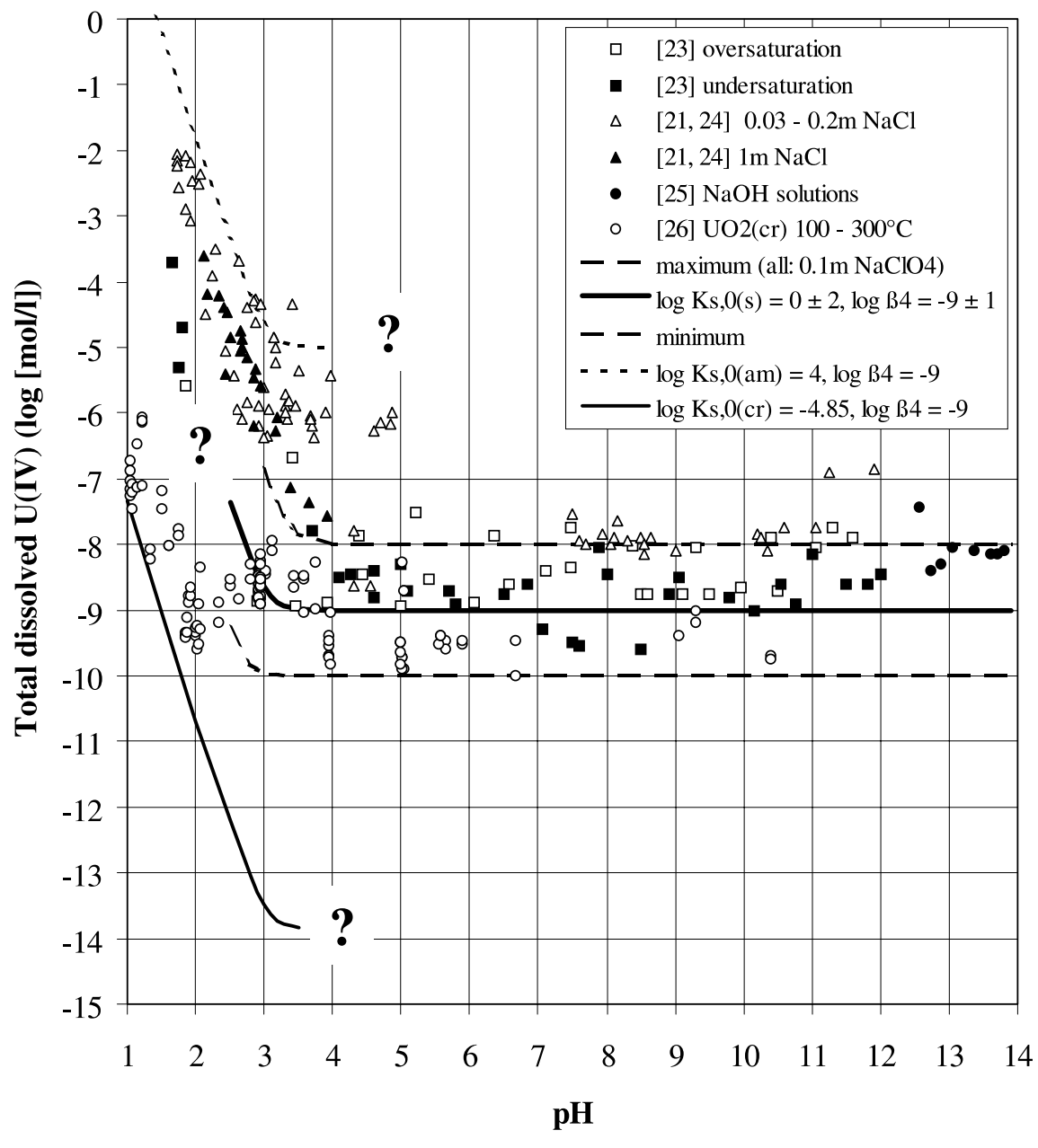

Fig. 5. Solubility data of the system U(IV)$\mathrm{H}_{2} \mathrm{O}$. The thick solid line is calculated using thermodynamic constants estimated in this review. Dashed lines represent the estimated uncertainty. The dotted line is calculated using $\log _{10} * K_{s, 0}{ }^{\circ}(\mathrm{am})=4$ [21]. The thin solid line is calculated using $\log _{10} * K_{s, 0}{ }^{\circ}(\mathrm{cr})=-4.85$ derived from $\Delta_{\mathrm{f}} G_{\mathrm{m}}{ }^{\circ}$ of $\mathrm{UO}_{2}(\mathrm{cr})$ [4].

\section{Uncertain data}

All thermodynamic constants in this database are uncertain to a varying degree. We estimated this uncertainty wherever possible, and as a consequence, most selected constants are associated with a \pm sign [3]. However, simply comparing and ranking the selected values according to their \pm uncertainty numbers does not tell the complete story. At least two additional classes of "especially uncertain" data have been identified: limiting values and "placeholders".

(1) Some of the selected stability constants are given as limiting values only or as approximate values without uncertainty estimates [3]:

$$
\begin{array}{ll}
\log _{10} \beta^{\circ} & \text { Reaction } \\
<6 & \mathrm{Ni}^{2+}+2 \mathrm{CO}_{3}{ }^{2-} \Leftrightarrow \mathrm{Ni}_{\left(\mathrm{CO}_{3}\right)_{2}{ }^{2-}} \\
\approx 1 & \mathrm{Ni}^{2+}+\mathrm{HCO}_{3}{ }^{-} \Leftrightarrow \mathrm{NiHCO}_{3}{ }^{+} \\
<-7.0 & \mathrm{Pd}^{2+}+2 \mathrm{Cl}^{-}+2 \mathrm{H}_{2} \mathrm{O} \Leftrightarrow \mathrm{PdCl}_{2}(\mathrm{OH})_{2}{ }^{2-}+2 \mathrm{H}^{+} \\
<4 & \mathrm{TcO}(\mathrm{OH})_{2}(\mathrm{aq})+2 \mathrm{H}^{+} \Leftrightarrow \mathrm{TcO}^{2+}+2 \mathrm{H}_{2} \mathrm{O}(\mathrm{l}) \\
\leq-19 & \mathrm{NpO}_{2}{ }^{2+}+3 \mathrm{H}_{2} \mathrm{O} \Leftrightarrow \mathrm{NpO}_{2}(\mathrm{OH})_{3}{ }^{-}+3 \mathrm{H}^{+} \\
\leq-33 & \mathrm{NpO}_{2}{ }^{2+}+4 \mathrm{H}_{2} \mathrm{O} \Leftrightarrow \mathrm{NpO}_{2}(\mathrm{OH})_{4}{ }^{2-}+4 \mathrm{H}^{+} \\
\leq-9.73 & \mathrm{PuO}_{2}{ }^{+}+\mathrm{H}_{2} \mathrm{O} \Leftrightarrow \mathrm{PuO}_{2} \mathrm{OH}(\mathrm{aq})+\mathrm{H}^{+}
\end{array}
$$

Because approximate data of this kind cannot be handled by conventional speciation programs, we were forced to treat these equilibrium constants as exact for the electronic version of the database, and the $\approx,<$, and $\leq$ signs had to be dropped. Therefore, should any species defined by one of these formation equations be of importance in the result of a speciation calculation, the approximate nature of this result should be always kept in mind.

(2) Some stability constants have been included in our database as "placeholders":

The $\mathrm{Se}(0) / \mathrm{Se}(-\mathrm{II})$ redox equilibrium, $\mathrm{Se}(\mathrm{s})+2 \mathrm{H}^{+}+$ $2 \mathrm{e}^{-} \Leftrightarrow \mathrm{H}_{2} \mathrm{Se}$ (aq), included in our database [3] has by no means the character of a well-established entity. Its value should be regarded as a rough estimate of the behaviour of a poorly known chemical reaction. On the other hand, it is of primary importance in the field of radioactive waste management. Excluding this equilibrium from the database might probably cause more erroneous results than including a rough estimate.

The stability constant for $\mathrm{ThHPO}_{4}{ }^{2+}, \log _{10} K^{\circ}=13 \pm 1$ (Table 1), is not recommended as our "best estimate" for Th phosphate complex formation. We included this value as a placeholder for missing Th phosphate complexes. It should serve as a guard in speciation calculations of Th phosphate systems, warning modellers about the possible importance of phosphate complex formation.

To some extent, aqueous metal silicate complexes are an entire class of "placeholders" [3]. There is ample evidence of strong complex formation with several metals but the stoichiometry of the complexes is not yet established. Different speciation schemes have been proposed to interpret experimental data, e.g. $1: 2$ complexes, chelates, or mixed Brought to you by | Lib4RI Eawag-Empa 
hydroxide-silicate complexes. Despite these ambiguities we decided to include several metal silicate complexes in our database (see Table 4) as guidelines for modellers. If such complexes are found to be of crucial importance in particular systems, additional experimental studies would be called for.

At present none of the conventional geochemical programs actually considers uncertainties of thermodynamic parameters. We have to deal with the sobering fact that application in routine modelling exercises degrades all efforts, no matter how zealous, to estimate uncertainties to "NUMBER \pm decoration". However, work is in progress to explore, in a consistent and systematic manner, the uncertainty space of thermodynamic equilibrium calculations. We expect that this ongoing research project will have a strong impact on the art of geochemical modelling. With that prospect in mind, our efforts to estimate uncertainties can be considered as an investment in future developments of geochemical modelling.

\section{Missing data}

In theory a thermodynamic database should be complete in terms of all relevant compounds and complexes. In practice this goal can only be approximated. It is a delicate balance between including high quality data only and filling gaps with estimated values and "placeholders" as discussed above. The guideline to keep this balance is provided by the question: "Is the missing entity of importance for the envisioned application of the database?"

In the case of Th(IV) and U(IV) hydrolysis we selected values for $\mathrm{ThOH}^{3+}, \mathrm{Th}(\mathrm{OH})_{4}(\mathrm{aq})$, and $\mathrm{UOH}^{3+}$ derived from potentiometric studies, and in addition an estimated value for $\mathrm{U}(\mathrm{OH})_{4}(\mathrm{aq})$ (Table 1). This estimate is of crucial importance for modelling the system $\mathrm{UO}_{2}(\mathrm{~s})-\mathrm{H}_{2} \mathrm{O}-\mathrm{CO}_{2}$ above $\mathrm{pH} 4$. However, we decided not to include estimated values for the complexes $\mathrm{Th}(\mathrm{OH})_{2}{ }^{2+}, \mathrm{Th}(\mathrm{OH})_{3}{ }^{+}, \mathrm{U}(\mathrm{OH})_{2}{ }^{2+}$, and $\mathrm{U}(\mathrm{OH})_{3}{ }^{+}$just for the sake of completeness. These complexes would change the Th(IV) and U(IV) solubility curves marginally only at low $\mathrm{pH}$, outside the range of applicability of our selected parameter set (see Figs. 4 and 5 and the detailed discussion in [19]).

However, a few cases of serious data gaps have been identified:

(1) In the case of tin no meaningful value for the $\mathrm{Sn}(\mathrm{IV}) / \mathrm{Sn}$ (II) redox equilibrium could be derived from experimental data, and no estimate was possible. As a consequence, the tin system is redox de-coupled in our database [3]. This means that two primary master species were selected, one for $\mathrm{Sn}$ (II) and one for $\mathrm{Sn}(\mathrm{IV})$, and it is not possible to model the behaviour of tin as a function of the redox potential.

(2) Solubility studies indicate the formation of strong $\mathrm{Zr}$ carbonate complexes [27]. This is not a surprise considering the behaviour of other tetravalent metals (Table 1). However, the experimental data are not sufficient to elucidate the stoichiometry of the limiting carbonate complex, i.e. to discern between a tetra- and a penta-carbonate complex. This prevents the derivation of any meaningful stability constant and no value can presently be recommended.
(3) In the case of ferric iron, solubility studies also indicate the formation of strong Fe(III) carbonate complexes. A detailed review of the experimental data revealed an unresolved ambiguity concerning the nature of the solubility limiting solid phase [20]. This ambiguity results in uncertainties of several orders of magnitude for Fe(III) carbonate equilibrium constants, and although the experimental data suggest that $\mathrm{Fe}(\mathrm{III})$ carbonate complexes predominate in some carbonate rich groundwaters, no equilibrium constants can be recommended. However, for exploring the possible effects of $\mathrm{Fe}(\mathrm{III})$ carbonate complexation in modelling exercises, estimates for an equilibrium constant are suggested, though not included in the database [3].

\section{Future data needs}

The most obvious future data needs concern the missing, uncertain, and conflicting data as identified above. Additional experimental studies are needed in the case of $\mathrm{Fe}(\mathrm{III})$ and $\mathrm{Zr}(\mathrm{IV})$ carbonate complexation, and in the case of the $\mathrm{Sn}(\mathrm{IV}) / \mathrm{Sn}$ (II) and the $\mathrm{Se}(0) / \mathrm{Se}(-\mathrm{II})$ redox couples. The molecular structure of metal silicate complexes needs clarification in order to remove the ambiguity in the speciation schemes of these complexes. A rather challenging topic of future research concerns the proposed change of crystalline tetravalent actinides, $\mathrm{AnO}_{2}$ (cr), to a solid with an amorphous surface layer as soon as the $\mathrm{An}^{4+}$ ion undergoes hydrolysis reactions. The consequences of such a reaction for thermodynamic equilibria, solubility and sorption of actinides are largely unexplored.

Ternary species must be considered in models of environmental systems. However, there is no chance to explore experimentally the huge number of possibly forming ternary species. For any specific system the modellers first have to estimate which ternary species might be important and only then experimental studies should be started. As an example, we showed that mixed hydroxide carbonate complexes of $\mathrm{U}^{4+}, \mathrm{Np}^{4+}$ and $\mathrm{Pu}^{4+}$ are of particular interest in carbonate rich ground waters [28]. Further experimental studies are needed to determine their stability constants.

Additional review work in forthcoming updates of our database should consider iron compounds and complexes. The iron system is thought to be of crucial importance in elucidating the redox behaviour of radioactive waste repositories. Preliminary applications indicate that the lack of data in the iron system is a source of major uncertainties associated with the definition of a redox potential. Hence, it is of little value to develop sophisticated redox models for radionuclides as long as the dominant redox processes in a repository are still poorly known.

Another field with a large potential for improvements concerns alumosilicate minerals which are of great importance in determining the chemistry of water in many rock types. In backfill clays alumosilicates are responsible for the retention (sorption, incorporation) of trace elements and may participate in determining the redox potential (incorporation of $\mathrm{Fe}(\mathrm{II}) / \mathrm{Fe}(\mathrm{III})$ ) and $\mathrm{pH}$ (silicate hydrolysis and(or) $\mathrm{H}^{+}$exchange). Related compound classes (i.e. calcium silicates and calcium aluminates) form the 
chemical backbone of cementitious material. The thermodynamic properties of these substances are still largely unexplored.

Ongoing research explores the behaviour of solid solutions. The ultimate goal of these projects involving experimental and modelling studies is the development of simple yet sufficiently accurate thermodynamic models of these systems. A future extension of our database should include the model parameters necessary for a consistent description of important solid solution systems.

Acknowledgment. We thank two anonymous reviewers for their valuable comments. Partial financial support by the Swiss National Cooperative for the Disposal of Radioactive Waste (Nagra) is gratefully acknowledged.

\section{References}

1. Pearson, F. J., Berner, U.: Nagra Thermochemical Data Base I. Core Data. Nagra Technical Report NTB 91-17, Nagra, Wettingen, Switzerland (1991) p. 70.

2. Pearson, F. J., Berner, U., Hummel, W.: Nagra Thermochemical Data Base II. Supplemental Data 05/92. Nagra Technical Report NTB 91-18, Nagra, Wettingen, Switzerland (1992) p. 284.

3. Hummel, W., Berner, U., Curti, E., Pearson, F. J., Thoenen, T.: Nagra/PSI Chemical Thermodynamic Data Base 01/01. Nagra Technical Report NTB 02-16, Nagra, Wettingen, Switzerland, and Universal Publishers/uPublish.com, Parkland, Florida, USA (2002) p. 585.

4. Grenthe, I., Fuger, J., Konings, R. J. M., Lemire, R. J., Muller, A. B., Nguyen-Trung, C., Wanner, H.: Chemical Thermodynamics of Uranium. Elsevier, Amsterdam (1992) p. 715.

5. Lemire, R. J., Fuger, J., Nitsche, H., Potter, P., Rand, M. H., Rydberg, J., Spahiu, K., Sullivan, J. C., Ullman, W. J., Vitorge, P., Wanner, H.: Chemical Thermodynamics of Neptunium \& Plutonium. Elsevier, Amsterdam (2001) p. 845.

6. Silva, R. J., Bidoglio, G., Rand, M. H., Robouch, P. B., Wanner, H., Puigdomènech, I.: Chemical Thermodynamics of Americium. Elsevier, Amsterdam (1995) p. 374.

7. Rard, J. A., Rand, M. H., Anderegg, G., Wanner, H.: Chemical Thermodynamics of Technetium. Elsevier, Amsterdam (1999) p. 544.

8. Grenthe, I., Hummel, W., Puigdomènech, I.: Chemical Background for the Modelling of Reactions in Aqueous Systems. In: Modelling in Aquatic Chemistry. (Grenthe, I., Puigdomènech, I., eds.) OECD Nuclear Energy Agency, Paris (1997).

9. Brown, P. L., Wanner, H.: Predicted Formation Constants Using the Unified Theory of Metal Ion Complexation. OECD Nuclear Energy Agency, Paris (1987).

10. Neck, V., Kim, J. I.: An electrostatic approach for the prediction of actinide complexation constants with inorganic ligands - application to carbonate complexes. Radiochim. Acta 88, 815 (2000).

11. Schwarzenbach, G.: The General, Selective, and Specific Formation of Complexes by Metallic Cations. In: Advances in Inorganic
Chemistry and Radiochemistry. (Emeléus, H. J., Sharpe, A. G., eds.) Academic Press, New York, (1961) Vol. 3.

12. Pearson, R. G.: Hard and soft acids and bases. J. Am. Chem. Soc. 85, 3533 (1963).

13. Nieboer, E., Richardson, D. H. S.: The Replacement of the nondescript term 'Heavy Metal' by a biologically and chemically significant classification of metal ions. Environ. Pollution (Ser. B) 1, 3 (1980).

14. Rai, D., Moore, D. A., Oakes, C. S., Yui, M.: Thermodynamic model for the solubility of thorium dioxide in the $\mathrm{Na}^{+}-\mathrm{Cl}^{-}-$ $\mathrm{OH}^{-}-\mathrm{H}_{2} \mathrm{O}$ system at $23{ }^{\circ} \mathrm{C}$ and $90^{\circ} \mathrm{C}$. Radiochim. Acta 88, 297 (2000).

15. Bundschuh, T., Knopp, R., Müller, R., Kim, J. I., Neck, V., Fanghänel, T.: Application of LIBD to the determination of the solubility product of thorium(IV)-colloids. Radiochim. Acta 88, 625 (2000).

16. Felmy, A. R., Rai, D., Mason, M. J.: The solubility of hydrous thorium(IV) oxide in chloride media: development of an aqueous ion-interaction model. Radiochim. Acta 55, 177 (1991).

17. Moon, H. C.: Equilibrium ultrafiltration of hydrolyzed thorium(IV) solutions. Bull. Korean Chem. Soc. 10, 270 (1989).

18. Baes, C. F., Jr., Meyer, N. J., Roberts, C. E.: The hydrolysis of thorium(IV) at 0 and $95^{\circ} \mathrm{C}$. Inorg. Chem. 4, 518 (1965).

19. Neck, V., Kim, J. I.: Solubility and hydrolysis of tetravalent actinides. Radiochim. Acta 89, 1 (2001).

20. Hummel, W.: Comment on "On the influence of carbonate in mineral dissolution: 1 . The thermodynamics and kinetics of hematite dissolution in bicarbonate solutions at $T=25^{\circ} \mathrm{C}$." (by Bruno, J., Stumm, W., Wersin, P., Brandberg, F.) Geochim. Cosmochim. Acta 64, 2167 (2000).

21. Rai, D., Felmy, A. R., Ryan, J. L.: Uranium(IV) hydrolysis constants and solubility product of $\mathrm{UO}_{2} \cdot x \mathrm{H}_{2} \mathrm{O}(\mathrm{am})$. Inorg. Chem. 29, 7852 (1990).

22. Shannon, R. D.: Revised effective ionic radii and systematic studies of interatomic distances in halides and chalcogenides. Acta Cryst. A 32, 751 (1976).

23. Yajima, T., Kawamura, Y., Ueta, S.: Uranium(IV) solubility and hydrolysis constants under reduced conditions. Mat. Res. Soc. Symp. Proc. 353, 1137 (1995).

24. Rai, D., Felmy, A. R., Sterner, S. M., Moore, D. A., Mason, M. J., Novak, C. F.: The solubility of Th(IV) and U(IV) hydrous oxides in concentrated $\mathrm{NaCl}$ and $\mathrm{MgCl}_{2}$ solutions. Radiochim. Acta 79, 239 (1997).

25. Ryan, J. L., Rai, D.: The solubility of uranium(IV) hydrous oxide in sodium hydroxide solutions under reducing conditions. Polyhedron 2, 947 (1983).

26. Parks, G. A., Pohl, D. C.: Hydrothermal solubility of uraninite. Geochim. Cosmochim. Acta 52, 863 (1988).

27. Pouchon, M. A., Curti E., Degueldre C., Tobler L.: The influence of carbonate complexes on the solubility of zirconia: new experimental data. Progr. Nucl. Energy 38, 443 (2001).

28. Hummel, W., Berner, U.: Application of the Nagra/PSI Thermochemical Data Base 01/01: Solubility and Sorption of Th, U, Np and Pu. PSI Internal Technical Report TM-44-01-04, Paul Scherrer Institut, Villigen, Switzerland (2001) p. 28.

29. Baes, C. F., Jr., Mesmer, R. E.: The Hydrolysis of Cations. John Wiley \& Sons, New York (1976) p. 489. 